\title{
Front Matter: Volume 7042
}

, "Front Matter: Volume 7042," Proc. SPIE 7042, Instrumentation, Metrology, and Standards for Nanomanufacturing II, 704201 (2 October 2008); doi: $10.1117 / 12.814683$

SPIE Event: NanoScience + Engineering, 2008, San Diego, California, United SPIE. States 


\title{
PROCEEDINGS OF SPIE
}

\section{Instrumentation, Metrology, and Standards for Nanomanufacturing II}

\author{
Michael T. Postek \\ John A. Allgair \\ Editors
}

10 August 2008

San Diego, California, USA

Sponsored and Published by

SPIE

Cosponsored by

NIST-National Institute of Standards and Technology (United States) 
The papers included in this volume were part of the technical conference cited on the cover and title page. Papers were selected and subject to review by the editors and conference program committee. Some conference presentations may not be available for publication. The papers published in these proceedings reflect the work and thoughts of the authors and are published herein as submitted. The publisher is not responsible for the validity of the information or for any outcomes resulting from reliance thereon.

Please use the following format to cite material from this book:

Author(s), "Title of Paper," in Instrumentation, Metrology, and Standards for Nanomanufacturing II, edited by Michael T. Postek, John A. Allgair, Proceedings of SPIE Vol. 7042 (SPIE, Bellingham, WA, 2008) Article CID Number.

ISSN 0277-786X

ISBN 9780819472625

Published by

SPIE

P.O. Box 10, Bellingham, Washington 98227-0010 USA

Telephone +1 3606763290 (Pacific Time) · Fax +1 3606471445

SPIE.org

Copyright (C) 2008, Society of Photo-Optical Instrumentation Engineers

Copying of material in this book for internal or personal use, or for the internal or personal use of specific clients, beyond the fair use provisions granted by the U.S. Copyright Law is authorized by SPIE subject to payment of copying fees. The Transactional Reporting Service base fee for this volume is $\$ 18.00$ per article (or portion thereof), which should be paid directly to the Copyright Clearance Center (CCC), 222 Rosewood Drive, Danvers, MA 01923. Payment may also be made electronically through CCC Online at copyright.com. Other copying for republication, resale, advertising or promotion, or any form of systematic or multiple reproduction of any material in this book is prohibited except with permission in writing from the publisher. The CCC fee code is $0277-786 \times / 08 / \$ 18.00$.

Printed in the United States of America.

Publication of record for individual papers is online in the SPIE Digital Library.

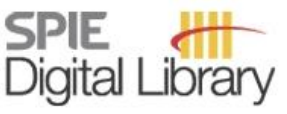

SPIEDigitalLibrary.org

Paper Numbering: Proceedings of SPIE follow an e-First publication model, with papers published first online and then in print and on CD-ROM. Papers are published as they are submitted and meet publication criteria. A unique, consistent, permanent citation identifier (CID) number is assigned to each article at the time of the first publication. Utilization of CIDs allows articles to be fully citable as soon they are published online, and connects the same identifier to all online, print, and electronic versions of the publication. SPIE uses a six-digit CID article numbering system in which:

- The first four digits correspond to the SPIE volume number.

- The last two digits indicate publication order within the volume using a Base 36 numbering system employing both numerals and letters. These two-number sets start with 00, 01, 02, 03, 04, 05 , $06,07,08,09,0 A, O B \ldots$. OZ, followed by 10-1Z, 20-2Z, etc.

The CID number appears on each page of the manuscript. The complete citation is used on the first page, and an abbreviated version on subsequent pages. Numbers in the index correspond to the last two digits of the six-digit CID number. 


\section{Contents}

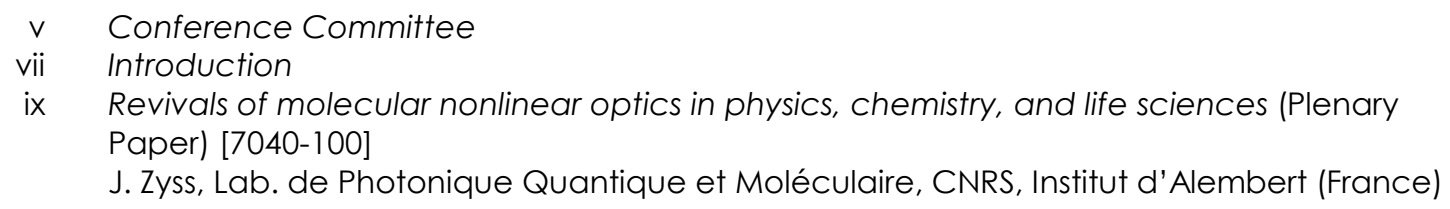

\section{SESSION $1 \quad$ INSTRUMENTATION AND METROLOGY I}

$704202 \quad$ Metrology at the nanoscale: what are the grand challenges? [7042-01]

K. W. Lyons, M. T. Postek, National Institute of Standards and Technology (United States)

$704203 \quad$ Ultra low capacitance high frequency IC probe [7042-02]

M. E. Jacob, D. A. Miller, L. Forbes, Oregon State Univ. (United States)

$704204 \quad$ High-speed AFM probe with micromachined membrane tip [7042-03]

B. Kim, B. H. Kwak, F. Jamil, Univ. of Massachusetts, Lowell (United States)

704205 Improved performance of an ultrastable measurement platform using a fieldprogrammable gate array for real-time deterministic control [7042-04]

A. B. Churnside, G. M. King, A. R. Carter, T. T. Perkins, National Institutes of Standards and Technology (United States) and Univ. of Colorado, Boulder (United States)

704206 Self-calibration of a dual-actuated single-axis nanopositioner using measurement transitivity with extensions to calibration of two-axis systems [7042-05]

Y. H. Jeong, Korea Polytechnic Univ. (United States); J. Dong, P. P. Ferreira, Univ. of Illinois at Urbana-Champaign (United States)

704207 Measurement of optical near field of a nanoscale aperture [7042-06]

R. Guo, Univ. of Science \& Technology of China (China) and Purdue Univ. (United States); W. Huang, Univ. of Science \& Technology of China (China); E. C. Kinzel, A. Raman, X. XU,

Purdue Univ. (United States)

\section{SESSION 2 MATERIALS AND METROLOGY}

704208 Test objects with right-angled and trapezoidal profiles of the relief elements [7042-07] Yu. A. Novikov, A.M. Prokhorov General Physics Institute (Russia); V. P. Gavrilenko, Ctr. for Surface and Vacuum Research (Russia); A. V. Rakov, A.M. Prokhorov General Physics Institute (Russia); P. A. Todua, Ctr. for Surface and Vacuum Research (Russia)

704209 Check of the quality of fabrication of test objects with a trapezoidal profile [7042-08] P. A. Todua, V. P. Gavrilenko, Ctr. for Surface and Vacuum Research (Russia); Yu. A. Novikov, A. V. Rakov, A.M. Prokhorov General Physics Institute (Russia) 
7042 OA Accuracy considerations for critical dimension semiconductor metrology [7042-09]

N. G. Orji, R. G. Dixson, National Institute of Standards and Technology (United States);

B. D. Bunday, J. A. Allgair, International SEMATECH Manufacturing Initiative (United States)

$7042 \mathrm{OB}$ Extraction of trench geometry and linewidth of nanoscale grating targets in (110)-oriented silicon using angle-resolved scatterometry [7042-10]

H. J. Patrick, KT Consulting, Inc. (United States) and National Institute of Standards and Technology (United States); T. A. Germer, M. W. Cresswell, National Institute of Standards and Technology (United States); B. Li, H. Huang, P. S. Ho, The Univ. of Texas at Austin (United States)

7042 OC Measurement of the parameters of the electron beam of a scanning electron microscope [7042-11]

V. P. Gavrilenko, Ctr. for Surface and Vacuum Research (Russia); Yu. A. Novikov, A. V. Rakov, A.M. Prokhorov General Physics Institute (Russia); P. A. Todua, Ctr. for Surface and Vacuum Research (Russia)

\section{SESSION 3 STANDARDS AND METROLOGY}

7042 OD Cellulose nanocrystals the next big nano-thing? [7042-12]

M. T. Postek, A. Vladar, J. Dagata, N. Farkas, B. Ming, National Institute of Standards and Technology (United States); R. Sabo, T. H. Wegner, J. Beecher, USDA Forest Service (United States)

7042 OE Measurement of oxide barrier-film thickness of Al alloy by electrochemical impedance spectroscopy at the nanometre scale [7042-13]

K. Habib, Kuwait Institute for Scientific Research (Kuwait)

7042 OF Toward in situ $x$-ray diffraction imaging at the nanometer scale [7042-14]

N. A. Zatsepin, R. A. Dilanian, A. Y. Nikulin, B. M. Gable, B. C. Muddle, Monash Univ. (Australia); O. Sakata, Japan Synchrotron Radiation Research Institute (Japan)

7042 OG Laser diagnostics for flame synthesis of nanostructured materials: instrumentation, metrology, and process control [7042-15]

X. Liu, Rutgers Univ. (United States)

$7042 \mathrm{OH} \quad$ Three-dimensional x-ray diffraction nanoscopy [7042-16]

A. Y. Nikulin, R. A. Dilanian, N. A. Zatsepin, B. C. Muddle, Monash Univ. (Australia)

\section{SESSION 4 INSTRUMENTATION AND METROLOGY II}

7042 0J Silica nanoparticle inline size measurement using refractive index gradient in a microfluidic cell [7042-18]

Y. Qiao, D. Hofeldt, B. Graebel, J. Ramthun, M. Dolezal, 3M Co. (United States)

Author Index 


\title{
Conference Committee
}

\author{
Symposium Chairs
}

David L. Andrews, University of East Anglia Norwich (United Kingdom) James G. Grote, Air Force Research Laboratory (United States)

Kevin J. Liddane, Oerlikon Optics USA Inc. (United States)

Conference Chair

Michael T. Postek, National Institute of Standards and Technology (United States)

Conference Co-Chair

John A. Allgair, SEMATECH, Inc. (United States) and Freescale Semiconductors, Inc. (United States)

Program Committee

Daniel J. C. Herr, Semiconductor Research Corporation (United States)

Mark D. Hoover, The National Institute for Occupational Safety and Health (United States)

David C. Joy, The University of Tennessee (United States)

Kevin W. Lyons, National Institute of Standards and Technology (United States)

Ndubuisi George Orji, National Institute of Standards and Technology (United States)

Ron L. Remke, SEMATECH, Inc. (United States)

Richard M. Silver, National Institute of Standards and Technology (United States)

John Small, National Institute of Standards and Technology (United States)

Mark T. Tuominen, University of Massachusetts/Amherst (United States)

Session Chairs

1 Instrumentation and Metrology I

Michael T. Postek, National Institute of Standards and Technology (United States)

John A. Allgair, SEMATECH, Inc. (United States) and Freescale Semiconductors, Inc. (United States) 
2 Materials and Metrology

Kevin W. Lyons, National Institute of Standards and Technology (United States)

Ndubuisi George Orji, National Institute of Standards and Technology (United States)

3 Standards and Metrology

Ndubuisi George Orji, National Institute of Standards and Technology (United States)

John A. Allgair, SEMATECH, Inc. (United States) and Freescale Semiconductors, Inc. (United States)

$4 \quad$ Instrumentation and Metrology II

Michael T. Postek, National Institute of Standards and Technology (United States)

Kevin W. Lyons, National Institute of Standards and Technology (United States) 


\section{Introduction}

We are in a time of great technological change in manufacturing. The pace of this change is increasing very rapidly and "nanomanufacturing" is slowly emerging as a viable entity. Instrumentation, metrology, and standards are the key infrastructural underpinnings of the emerging nanotechnology enterprise. Advances in fundamental nanoscience and, ultimately, manufacturing of new nanotechnology-based products all depend to a great degree on our capability to accurately and reproducibly measure the properties and performance characteristics at the nanometer scale. Both physical and documentary standards are needed to ensure product consistency worldwide. New nanotechnology-based industries that mass-produce products will require high-performance, cost-effective, reliable instrumentation and improved measurement methods to meet the requirements of effective manufacturing. Along with these comes the need for effective collection, transmission, and interpretation of measurement information and data.

As new nanostructures emerge and are fabricated, assembled, and manufactured into usable products, standardization for instrumentation and metrology will be vital for providing quality control and ensuring reproducible performance. Globally accepted standards for measurement, and identification of properties and structures at the nanoscale, are necessary to ensure an even playing field for products to compete successfully in the International marketplace. The 2008 SPIE Conference on "Instrumentation, Metrology and Standards for Nanomanufacturing" continued this theme begun in 2007. This is a forward-looking conference geared to assist the manufacturers of nano-based products to have the tools, measurement infrastructure, and standards needed for mass production, so that they may be able to take advantage of the economies of scale. The goal of this conference is to become the forum for the exchange of foundational information and discussion of instrumentation, metrology, and standards which are the key to the success of nanomanufacturing, because "if you cannot measure it you cannot manufacture it."

Michael T. Postek 
Downloaded From: https://www.spiedigitallibrary.org/conference-proceedings-of-spie on 26 Apr 2023

Terms of Use: https://www.spiedigitallibrary.org/terms-of-use 